\title{
INTRODUCTION: HUMAN RIGHTS COMPLIANCE AND CORPORATE CRIMINAL LIABILITY
}

In recent years, human rights violations in emerging and developing countries by multinational companies, their subsidiaries or production partners have come more into the public eye. There is a growing debate above all in human rights circles with a view to create accountability mechanisms for companies involved in serious human rights violations often amounting to international crimes. However, the criminal law implications of such accountability mechanisms are not sufficiently addressed, let alone theorised. Thus, we decided to make them the focus of this special issue of the Forum. It is a product of an international symposium on the question of criminal liability of companies for human rights violations "Corporate Compliance and Human Rights" which took place at Freie Universität Berlin in February 2018 and was organized by Carsten Momsen (Freie Universität Berlin), Thomas Grützner (Baker \& McKenzie), Miriam Saage-Maaß (European Center for Constitutional and Human Rights Berlin and Tobias Singelnstein (Ruhr Universität Bochum).

Given the increasing (national) practice it is high time to reflect more profoundly, from a comparative-international perspective, on the multiple criminal law issues of criminal accountability for multinational companies, their subsidiaries and production partners. Cases are rarely so clearcut as the ones of businessmen who supply poison gas or weapons to crisis regions, often violating international embargoes, and who can therefore be prosecuted and convicted for aiding and abetting war crimes. At any rate, it is increasingly the affected people themselves who, with the help of a transnational network of human rights organizations and lawyers, hold the responsible managers and companies legally responsible in the

\footnotetext{
* Kai Ambos Georg-August-Universität Göttingen, Göttingen, Germany. E-mail: kambos@gwdg.de.

** Carsten Momsen Freie Universität Berlin, Berlin, Germany. E-mail: carsten. momsen@fu-berlin.de.
} 
countries in which the company has its headquarters. As a consequence, an awareness begins to develop that the parent companies based in the industrial countries could also be liable for damages caused in the production countries.

Yet, despite the mentioned increase in national practice, the criminal law practice in the developed "headquarter" countries just begins to deal with such crimes and human rights violations. While there are selective investigations and prosecutions, for example against managers of German companies because of the expulsion of rural populations in connection with a dam construction in Sudan, a systematic approach in dealing with human rights violations by companies from a criminal law perspective is still missing. While there is growing international (soft) law at various levels, from the international UN Guiding Principles down to the company's internal code of conduct, this law does not deal with the nitty gritty of criminal law attribution. This is demonstrated by the first paper in this issue, written by Kai Ambos, who looks at the emerging international economic criminal law, that is, the approaches from international criminal law (ICL), often a product of human rights discourse, to tackle our problem. Ambos tries to lay the foundations of criminal liability of companies from an ICL perspective, focusing of the appropriate model of liability and the possible forms of participation.

After that Carsten Momsen and Mathis Schwarze analyze the current status of hard and soft law in various jurisdictions. They present a regulation model and show the risks of an increasing liability for negligence in the case of different negligence standards. Their contribution makes clear that accountability for human rights violations seems inevitable to lead to an extension of criminal law as a whole, particularly in the area of negligence. Mark Pieth examines the general choices and asks whether and what synergies can exist between corporate compliance and social obligations for the protection of human rights. Miriam Saage-Maaß uses the "Merowe-Dam Project" as a paradigmatic example to show when and under what conditions legitimate business activities turn into criminally relevant conduct. It entails a concept of guarantor liability in the context of international business activities. Thomas Firestone and Kerry Contini use the "Global Magnitsky Act" as an example of how the justiciability of human rights violations can be established throughout the world under national law. Since 2016, this law, the only one of its kind, has allowed the U.S. judicial authorities to sanction human 
rights violations against foreign legal entities. They analyse the background and opportunities of such an instrument.

We thank all authors for their papers and hope that this very timely special issue will make at least a modest contribution on the debate of (criminal law) accountability of multinational companies for (serious) human rights violations. 